\title{
The Factors Increasing the Elderly Independence Living with the Family in the House
}

\author{
Mujahidatul Musfiroh ${ }^{1}$, Ika Sumiyarsi ${ }^{2}$, \\ \{mujahidatul_m@staff.uns.ac.id ${ }^{1}$, ikasumiyarsi@gmail.com² ${ }^{2}$. \\ Midwifery Department, Faculty of Medicine, Universitas Sebelas Maret, Surakarta, Central Java, \\ Indonesia ${ }^{1,2}$
}

\begin{abstract}
The decrease in physiological and cognitive functions of the elderly affects their independence. Its reduction could disrupt their daily activities from bathing, dressing, eating, defecating, urinating, to moving. The elderly independence is influenced by internal and external factor of the elderly. This research aims to investigate the factors increased the elderly independence in the houses as an effort to enhance their quality of life. Analytical observational design was involved with a cross-sectional approach. 102 samples obtained by total sampling technique. The data collection used a research instrument and modified Katz index to investigate the independence of the elderly. The data analysis was bivariate with chi-square test and multivariate with logistic regression test. The result of bivariate analysis shows the factors increasing the elderly independence and their health problems $\mathrm{p}=0,0000$ and $\mathrm{OR}=0,043$, movement disorder of the elderly $\mathrm{p}=0,0000$ and $\mathrm{OR}=0,038$, family support $\mathrm{p}=0,006$ and $\mathrm{OR}=3,157$, and the elderly's age with $\mathrm{p}=0,0000$ and $\mathrm{OR}=0,141$. The multivariate analysis shows the elderly health problems $(\mathrm{OR}=0,182)$, movement disorder $(\mathrm{OR}=0,153)$, family support $(\mathrm{OR}=4,342)$ and the elderly's age $(\mathrm{OR}=0,260)$ simultaneously influenced the level of elderly independence. The result indicates that the elderly independence will increase due to family support, age less than 69 years old, absence in health issues, and no record of movement disorder.
\end{abstract}

Keywords: elderly, elderly independence, family support

\section{Introduction}

Indonesia is stepping to the era of the aging structured population due to the increase in the number of elderly in Indonesia per year. The percentage of the elderly population in Indonesia is predicted to be increased from $9 \%$ in 2015 to $19,8 \%$ in 2045 [1]. The island inhibited by the most elderly in Indonesia is Java and Bali [2]. The increase in the number of elderly should be accompanied by the effort to increase the elderly independence; therefore, the elderly will no longer become the family burden, and they can live their lives meaningfully and happily [3]. The elderly independence is the elderly ability to do the daily activities independently without the assistance of the family, friend as well as the elderly ability to keep the physical and mental condition of the elderly. The elderly independence covers relative independence, autonomy, spatial independence, social independence [4]. The elderly independence is influenced by age, mobility, health condition, social condition, and family support [5], [6].

This research is expected to give the illustration of the factors influencing elderly independence in the house. Therefore, the elderly can get their independence in doing their daily activities and do not become the burden of the family or community. The elderly independence leads them to have the feeling that they are needed and to live their lives happily. 


\section{Materials and Method}

The research was an analytical observational research design with a cross-sectional approach. This research was aimed at analyzing the factors influencing the elderly independent living with the family. This research was carried out in Banyuagung Kadipiro Village Banjarsari Sub-district Surakarta. The population of this research was the family living with the elderly in Banyuagung Kadipiro Village Banjarsari Sub-district Surakarta in 2017. The sample of this research was obtained using simple random sampling technique. Simple random sampling technique is used because all of the elderly population has an equal opportunity to be chosen as the research sample. The samples of this research were 102 respondents.

The instruments used in this research were the questionnaire containing the elderly data, the statement of the family support to the elderly activities, observation sheet of on the level of elderly independence using modified Katz independence index. The research process was started by proposing the research permission, determining the respondent, and collecting the data. The data collection was done by approaching the respondent using door to door technique. The respondents were asked to fill in the questionnaire of the family support as well as the observation sheets of the elderly independence.

The data analysis used chi-square analysis test to find out the relationship between the variable of elderly health problems, elderly movement disorder, elderly age, and family support to elderly independence. Meanwhile, the logistic regression analysis test is used to find out the factors influencing the elderly independence living with the family.

\section{Results}

\subsection{Result of Bivariate Analysis Test}

Table 1 Cross Table between the Variable of Elderly Health Problems and Elderly Independence

\begin{tabular}{lcccc} 
& \multirow{2}{*}{ Variable } & \multicolumn{2}{c}{ Elderly Independence } & \multirow{2}{*}{ Total } \\
\cline { 3 - 4 } & & Low & High & \\
\hline Elderly Health & No Problem & 6 & 52 & 58 \\
Problem & Problem Exists & 32 & 12 & 44 \\
& Total & 38 & 64 & 102 \\
\hline
\end{tabular}

Table 1 shows that the elderly that has no health problem is 58 respondents, and the elderly that has high independence level is 52 respondents.

Table 2 Cross table between the Variable of Elderly Movement Disorder and Elderly Independence

\begin{tabular}{llccc}
\hline & \multirow{2}{*}{ Variable } & \multicolumn{2}{c}{ Elderly Independence } & \multirow{2}{*}{ Total } \\
\cline { 3 - 4 } \multicolumn{2}{l}{} & Low & High & 64 \\
Elderly Movement & No Disorder & 8 & 56 & 116 \\
Disorder & Disorder Exists & 30 & 8 & 102 \\
\hline
\end{tabular}

Table 2 shows the elderly that has no movement disorder is 64 respondents, while the elderly that has high independence is 56 respondents.

Table 3 Cross Table between the Variable of Family Support and Elderly Independence

\begin{tabular}{ccccc}
\hline \multicolumn{2}{c}{ Variable } & \multicolumn{2}{c}{ Elderly Independence } & \multirow{2}{*}{ Total } \\
\cline { 3 - 4 } & Low & Low & High & \\
\hline \multirow{2}{*}{ Family Support } & Low & 21 & 18 & 39 \\
& High & 17 & 46 & 63
\end{tabular}


Total

38

64

Table 3 shows that the family giving high support on the daily activities of the elderly is 63 respondents, while the elderly that has high independence and high family support is 46 respondents.

Table 4 Cross Table between the Variable of Elderly Age and Elderly Independence

\begin{tabular}{llccc} 
& Variable & \multicolumn{2}{c}{ Elderly Independence } & \multirow{2}{*}{ Total } \\
\cline { 2 - 4 } Elderly Age & Less than 69 years & 9 & High & \multirow{2}{*}{53} \\
& old & & 44 & \multirow{2}{*}{49} \\
& $\begin{array}{l}\text { More than 69 } \\
\quad \text { years old }\end{array}$ & 29 & 20 & 102 \\
\hline & Total & 38 & 64 & \\
\hline
\end{tabular}

Table 4 shows that the elderly of less than 69 years old is 53 respondents, while the elderly that has high independence is 44 respondents.

Table 5 The Result of Bivariate Analysis

\begin{tabular}{lcc}
\hline \multicolumn{1}{c}{ Variable } & Significance (5\%) & Odds Ratio \\
\hline Elderly Health Problems & 0.000 & 0.043 \\
Elderly Movement & 0.000 & 0.038 \\
Disorder & & \\
Family Support & 0.006 & 3.157 \\
Elderly Age & 0.000 & 0.141 \\
\hline
\end{tabular}

Table 5 shows the result of bivariate analysis among the variables of elderly health problems, elderly movement disorder, family support, elderly age, and elderly independence. The bivariate analysis that used Chi-Square test shows that there is a relationship between elderly health problems, elderly movement disorder, family support, elderly age, and elderly independence. The elderly having health problem has a lower risk of 0.043 times to high independence. Elderly having movement disorder has a lower risk of 0.038 to the high independence. Family support has the possibility of 3.157 to the high independence. The elderly who is more than 69 years old has the risk of 0.141 to the high independence.

\subsection{The Result of Multivariate Analysis}

Table 6 Result of Multivariate Analysis

\begin{tabular}{llll}
\hline \multicolumn{1}{c}{ Variable } & Significance (5\%) & Odds Ratio \\
\hline Elderly Health Problem & 0.017 & 0.182 & \\
Elderly Movement Disorder & 0.007 & 0.153 & \\
Family Support & 0.026 & 4.342 & \\
Elderly Age & 0.042 & 0.260 \\
\hline
\end{tabular}

Table 6 shows the result of multivariate analysis with the variable of elderly health problems, elderly movement disorder, family support, elderly age, and elderly independence. The multivariate analysis that used logistic regression test shows that elderly health problems, elderly movement disorder, family support, and elderly age simultaneously influence elderly independence. Family support has the risk of 4.342 times to influence high elderly independence, respectively the elderly age with the risk of 0.260 times, the elderly health problem with the risk of 0.182 times, and elderly movement disorder with the risk of 0.153 times. The result of the multivariate analysis shows that family support is the greatest factor in influencing elderly independence. 


\section{Discussion}

The elderly independence is the factor determining the elderly happiness in living their lives and as the benchmark of the level of elderly productivity - the higher the elderly independence, the lower the family burden in fulfilling the function of the family. The research result shows that elderly independence is influenced by elderly health problems, elderly movement disorder, family support, and elderly age. The elderly that has no health problem or the healthy elderly is the elderly that can do the daily activities without any obstacles or difficulties. The healthy elderly have higher independence than that having a health problem. The elderly health problem reduces the elderly daily activities due to age. Therefore, the elderly experiencing a health problem has low independence [7]. For instance, the elderly having sight disorder experiences the limitation in doing the daily activities, so independence is low [8].

The condition of elderly health correlates with the elderly functional disability in doing structured activity. The healthy elderly have individual autonomy, so independence is high.

[9] The elderly health condition has a higher possibility of 86 times to be independent in doing the daily activities [6]. The elderly movement disorder is the elderly limitation to move, so the elderly are dependent on doing the daily activities. The elderly movement disorder is caused by the sore, joint stiffness, balance disorder, psychological disorder, and fear to fall [10]. The elderly movement disorder increases the elderly risk to fall down. Therefore, the elderly ten to be dependent on the surrounding people of family to do the daily activities. The elderly dependence on the surrounding people or family causes low independence [11].

The elderly movement disorder is also caused by backache. Backache in the elderly causes the change of elderly physical activities to be low or moderate. The elderly independence in doing the daily activities may be caused by the backache, while the elderly activities pattern causes the backache. Thus, the elderly movement disorder due to a backache can be prevented by improving the elderly daily activities pattern and increase the elderly independence in doing daily activities [12]. The elderly movement disorder can be the obstacle factor and the supporting factor of elderly independence.

The family factor that can influence the elderly independence is family support. Family support is the aid for the elderly to attain independence in treating themselves. The provision of family support to the elderly is influenced by two factors: the education level of a family member and the positive family behavior to the family support [13]. The family supports that can be given to the elderly are instrumental, informational, evaluative, and emotional support [14],[15]. The family support to the elderly is given to increase the elderly comfort in doing the daily activities as well as to make them happy and charmed. The family support can also increase the quality of life of the elderly, so the elderly will be more healthy and happy [16]. The provision of family support to the elderly reduces the risk of chronic disease. The higher the family support, the greater the elderly possibility to do daily activities [17]. The family support greatly influences the elderly independence since it can increase the health status of the elderly to be independent [6]. High family support leads to high elderly independence. The high family support can increase the feeling of comfort, the feeling of protection, the feeling of security, and the feeling of satisfaction [18], [19]. The high family support can increase the elderly satisfaction and quality of life, so the elderly can do daily activities independently.

The elderly age influences the physical ability of the elderly. The increasing age of the elderly rapidly reduces their daily activities. Thus, the decrease of physical ability of the elderly becomes the risk factor of the elderly in doing daily activities [7]. The elderly independence in doing daily activities is also influenced by the mental health factor of the elderly. The elderly with the mental disorder experience the degradation of body function and mobilization ability, so the elderly have low independence[20].

The elderly condition that has no health problems has no movement disorder, is less than 69 years old, and has high family support become the factors influencing the level of elderly independence. The elderly independence is influenced by age, mobilization, health condition, 
social condition, and family support [5]. The greatest factor that influences elderly independence is high family support.

\section{Conclusion}

The family that gives high support has the member that is less than 69 years old, has no health problem, and has no movement disorder cause high elderly independence. The elderly independence that is maintained can improve the elderly quality of life. Therefore, the elderly can have the feeling that they matter and that they do not give the burden to the family.

Acknowledgments. We express our gratitude to all elderly cadres in Banyuagung Kadipiro Village Banjarsari Sub-district Surakarta, an alumnus of D-4 Midwives Educator in the Medicine Faculty of Universitas Sebelas Maret Surakarta that has helped us in this research.

\section{References}

[1] Central Bureau of Statistic Indonesia 2018 Proyeksi Penduduk Indonesia 2015-2045 Hasil SUPAS (2015)

[2] Effendi $F$ and Makhfudli.: Keperawatan Kesehatan Komunitas. Teori dan Praktik dalam Keperawatan (Jakarta : Salemba Medika). pp. 56-60. (2009)

[3] Maryam RS . Mengenal Usia Lanjut dan Perawatannya (Jakarta : Salemba Medika). pp. 36-50. (2008)

[4] Hillcoat-Nalletamby S.: The meaning of "independence" for older people in different residential settings J. Gerontol B Psychol Sci Soc Sci. Vol. 69, pp. 419-30. (2014)

[5] Marlita L, Saputra R and Yamin M.: Faktor-faktor yang Mempengaruhi Tingkat Kemandirian Lansia dalam Melakukan Activity Daily Living (ADL) di UPT PSTW Khusnul Khotimah J. Keperawatan Abdurrab. Vol. 1, pp. 64-8. (2018)

[6] Kodri and Rahmayati E.: Faktor yang Berhubungan dengan Kemandirian Lansia dalam Melakukan Aktivitas Sehari-hari J.Keperawatan. Vol. 12, pp. 81-9. (2016)

[7] Aron S B .: Total Daily Activity Declines More Rapidly With Increasing Age in Older Adults Arch Gerontol Geriatr. Vol. 58, pp. 74-79. (2014)

[8] Daien V .: Visual acuity thresholds associated with activity limitations in the elderly The Pathologies Oculaires Liées à l'Age study Acta Ophthalmol. Vol. 92, pp. 500-6. (2014)

[9] Mattos IE .: Factors associated with functional incapacity in elders living in long stay institutions in Brazil. A cross-sectional study BMC Geriatr. Vol. 15, pp. 47. (2014)

[10] Norkasiani and S Tamher.: Kesehatan Usia Lanjut dengan Pendekatan Asuhan Keperawatan (Jakarta : Salemba Medika). pp. 8-19. (2011)

[11] Kamel MH, Abdulmajeed AA and Ismail Sel-S.: Risk factors of falls among elderly living in urban Suez-Egypt. Pan Afr Med J. Vol. 14, pp. 9-19. (2007)

[12] De la Cruz-Sánchez E1 $\therefore$ Back pain and restricted daily physical activity in the Spanish adult population An Sist Sanit Navar. Vol. 35, pp. 241-9. (2012)

13] Sugisawa H, Nakatani Y and Shimizu Y.: A study of family support, health state and medical care among functionally dependent elderly in Shanghai China Nihon Koshu Eisei Zasshi. Vol. 38, pp. 546-52. (1991)

[14] Setiadi.: Konsep Dan Proses Keperawatan Keluarga Edisi Pertama (Yogyakarta: Graha Ilmu). pp. 818. (2008)

[15] Friedman M M.: Buku Ajar Keperawatan Keluarga : Riset, Teori, Dan Praktik Edisi 5 (Jakarta: EGC). pp.8-10. (2010)

[16] Liu H .: The quality of life and mortality risk of elderly people in rural China: the role of family support Asia Pac J. Public Health. Vol. 27, pp. 2232-45. (2015)

[17] Yuan SC : How family support affects physical activity (PA) among middle-aged and elderly people before and after they suffer from chronic diseases Arch Gerontol Geriatr. Vol. 53, pp. $274-$ 7. (2011) 
[18] Bertha I .: Apoyo social y familiar al adulto mayor del área urbana en Angelópolis Colombia 2011 Rev salud pública. Vol. 17, pp. 848-860. (2015)

[19] Shen Y and Yeatts DE.: Social support and life satisfaction among older adults in China. Familybased support versus community-based support Int. J. Aging Hum Dev. Vol. 77, pp. 189-209. (2013)

[20] Dirik A, Cavlak U and Akdag B.: Identifying the relationship among mental status, functional independence and mobility level in Turkish institutionalized elderly: gender differences Arch Gerontol Geriatr. Vol. 42, pp. 339-50. (2006) 